\title{
PERFORMATIZANDO A LEITURA DO TEXTO DRAMÁTICO INFANTIL: UMA PROPOSTA PARA SALA DE AULA
}

\section{PERFORMING THE READING OF THE DRAMATIC TEXT FOR CHILDREN: A CLASSROOM PROPOSAL}

\begin{abstract}
Aline Oliveira Arruda* Lanaiza do Nascimento Silva Araújo** Márcia Tavares**

Resumo: Um determinado modo de ler o texto literário pode oportunizar ao discente um novo direcionamento para compreender a significação de palavras e sentidos, cuja experimentação pode ser viável através de outros meios metodológicos. Um exemplo disso é a performance, uma vez que a leitura se desenvolve de forma oralizada (e em movimento), individual e em grupo. Nessa perspectiva, objetivamos apresentar uma proposta de leitura do texto dramático infantil para a sala de aula por meio da leitura do texto Maria Roupa de Palha, de Lourdes Ramalho (2008), destacando o método performático como instrumento para ler o texto dramatúrgico. Metodologicamente, discorremos sobre a leitura do texto dramático, trouxemos informações sobre a autora do livro e a obra corpus de nossa investigação, apresentando, por fim, uma proposta para ser desenvolvida com alunos do Ensino Fundamental. Nossos pressupostos teóricos estão fundamentados principalmente em Kefalás (2010; 2018), Grazioli (2007) e Camaroti (2005), dentre outros.

Palavras-chave: Maria Roupa de Palha. Lourdes Ramalho. Literatura dramática infantil. Leitura Performática

Abstract: A certain way of reading the literary text may give the student a new direction to understand the meaning of words and senses, whose experimentation may be viable through other methodological modes. An example of this is a performance, once the reading develops in an oral way (and by the use of gestures), individually and in groups. In this perspective, we intend to present a proposal to read, for the classroom, the children's dramatic text Maria Roupa de Palha, written by Lourdes Ramalho (2008), highlighting the performatic method as an instrument to read the dramaturgical text. Methodologically, we discuss the reading of the dramatic text, we brought information about the authorof the book, and the corpus worked in our investigation, finally, presenting a proposal to be developed with elementary school students. Our theoretical assumptions are mainly based on Kefalás (2010, 2018), Grazioli (2007) and Camaroti (2005), among others.
\end{abstract}

Key-words: Maria Roupa de Palha. Lourdes Ramalho. Children Dramatic Literature. Performatic Reading.

\footnotetext{
* Mestranda do Programa de Pós-Graduação em Linguagem e Ensino da Universidade Federal de Campina Grande - PPGLE/UFCG. Graduada em Letras - Língua Espanhola pela Universidade Federal de Campina Grande - UFCG (2016). Integrante do Grupo de Pesquisa Abordagens de Textos Literários na Escola. E-mail: alinearrudaufcg@gmail.com

** Doutora em Literatura Comparada pelo Programa de Pós-Graduação em Estudos da Linguagem da Universidade Federal do Rio Grande do Norte (2017). Atualmente é professora substituta de Língua Portuguesa e Literatura do Instituto Federal de Ciência e Tecnologia do Rio Grande do Norte. E-mail: lanaizasilva@yahoo.com.br

*** Professora da Universidade Federal de Campina Grande. Faz parte do quadro permanente do Programa de Pós-graduação em Linguagem e Ensino da mesma universidade. Tem experiência na área de Literatura, atuando principalmente nas seguintes áreas: Literatura Infantil e juvenil, ilustração do livro infantil, Literatura no ensino infantil e fundamental. E-mail: tavares.ufcg@ gmail.com
} 


\section{INTRODUÇÃO}

O teatro surge inicialmente na Grécia, e difunde-se no Ocidente, perpassando gerações que se encantaram com espetáculos da tragédia à comédia. Assim, apontamos, segundo Ferreira (2012), o espetáculo como:

[...] todo aquele acontecimento que envolve, como mínimo para sua existência, um ator, um espectador e uma interação estética [...]. No entanto, cabe ao espectador também ser um criador, ao construir, a partir de suas experiências e vivências, significados e sentidos únicos [...] (FERREIRA, 2012, p. 14).

Percebemos que o teatro, além de envolver o ator na representação cênica com o espectador, também se envolve nessa interação estética do texto dramatúrgico e o leitor, pois é por meio da leitura que se constrói a cena, seja ela apenas no imaginário de quem ler ou na ação decorrente da encenação. Assim, sabemos que o teatro se manifesta através da representação, no entanto, buscamos com a nossa pesquisa, mediante o estimulo à leitura, mostrar que podemos construir o nosso próprio espetáculo imaginário e, assim, construir uma ação interna estimulada pela leitura.

Segundo Grazioli (2007, p. 22), “[...] o teatro é uma arte de caráter revolucionário e transformador". Nesse sentido, o teatro possibilita ao ser humano perceber a si e o outro, em seus mais variados atos, contribuindo para a formação educacional de maneira espontânea e diversificada.

A pesquisadora Maria da Glória Magalhães dos Reis (2008, p. 46) destaca que: "[...] o teatro não produz apenas nos espectadores o despertar das fantasias, mas também às vezes o despertar da consciência, um não indo talvez sem o outro, como diz Brecht, pela associação do prazer e da reflexão". Compreendemos, portanto, que o teatro, no ato de ler, estimula sensações que vão além de suas emoções, pois a arte teatral transcende o ser, proporcionando-lhe um novo caminho para o aprendizado a partir da reflexão de tudo que está ao seu redor. Segundo Jouve (2002, p. 79):

Se o leitor pode realizar uma performance (atualizar os diferentes níveis de um texto), é porque dispõe de uma competência. Segundo Eco, a competência do leitor compreende, pelo menos idealmente, o conhecimento de um "dicionário de base" e "regras de correferência", a capacidade de interpretar o "hipercódigo retórico e estilístico", uma familiaridade com os "cenários comuns e intertextuais" e, enfim, uma visão ideológica.

Percebemos que o conhecimento do dicionário refere-se à base semântica existente no leitor, para que ele possa adentrar na leitura que, ladeada pelas regras de correferência, possibilita a compreensão, tanto para a enunciação quanto para a identificação do que se está lendo. Além disso, o hipercódigo retórico e estilístico faz com que a leitura possa ser caracterizada pela interpretação, levando ao reconhecimento do texto pela intertextualidade, possibilitando a recepção entre leitor e a obra, oportunizando a formação das suas próprias convicções.

No que consiste ao teatro infantil, este apresenta seus primeiros registros na China, provavelmente surgido no século II a.C. com apresentações de bonequeiros mambembes, cujos espetáculos eram encaminhados ao público adulto, muitas vezes de improviso, e sua função era entreter a burguesia (PEREIRA, 2005). Apenas tempos 
depois, esses espetáculos foram direcionados para as crianças. De acordo com Camarotti (2005, p. 161):

O requisito indispensável para que se tenha teatro infantil é colocar a criança como elemento prioritário, respeitando-a em toda a dimensão de sua realidade. Teatro infantil é, pois, aquele em que a criança ou é responsável pela atividade como um todo, ou se constitui na fonte principal da sua alimentação, isto é, um teatro no qual é linguagem da criança e o seu ponto de vista que predominam e orientam todos os setores de sua realização.

Compreendemos assim que o universo da criança deve ser respeitado, para que o teatro infantil possa se consolidar e esse processo de teatralização ganhe novos horizontes, difundindo-se no mundo. Dessa forma, o teatro infantil mergulha sua linguagem para a criança e começa a ocupar o espaço que lhe é de direto no âmbito da literatura.

No Brasil, o texto dramático escrito destinado ao público infantil ganha destaque no ano de 1948, com a montagem da peça $O$ casaco encantado, de Lúcia Benedetti. Assim, nesse período, o que o cenário brasileiro representava eram peças em que predominava a ideia de um teatro moralizante feito por crianças, geralmente nos espaços escolares, ou em outros espaços alternativos (LÚCIO, 2005). No entanto, foi com Maria Clara Machado que o gênero começou a ser visto de outra forma, pois atores adultos encenavam as obras escritas por ela, cuja produção dramatúrgica buscava respeitar a linguagem e o universo desse público.

O texto teatral, seja ele para o público infantil ou adulto, tem gerado efeitos comunicativos entre as pessoas na sociedade, haja vista que é um gênero que critica, denuncia ou enaltece diversos temas, fazendo com que o ser percebido seja visto na sociedade com voz e vez ao expressar sua opinião.

Em nosso trabalho, consideramos a importância desse gênero no ensino e aprendizagem na formação do leitor, por estarmos focando nossa investigação no processo de leitura do texto dramático, com a obra Maria Roupa de Palha, de Lourdes Ramalho (2008). Neste sentido, acreditamos que a leitura é essencial na construção de sentidos e novos aprendizados, pois, segundo Jouve (2002, p. 19): “[...] o charme da leitura provém em grande parte das emoções que ela suscita", favorecendo assim a interação e o diálogo da obra com o leitor.

Nesse mesmo ponto de vista, a leitura destacada por Manguel (1997) nos direciona a um prazer por meio dos leitores e suas artes, gestos, responsabilidade e poder, pois uma vez que ao ler não estamos sozinhos, a leitura nos servirá de elo para destacar essa relação do leitor e o texto envolvendo, cumplicidade e entrega.

Assim, diante de um contexto tão amplo no qual a leitura está inserida, lembramos que trabalhamos aqui com um gênero dificilmente lido em sala de aula, visto que este se diferencia dos demais gêneros textuais literários, pelo fato de não ser um texto escrito apenas para a leitura, mas também para ser encenado. Por esta razão, consideramos a nossa proposta relevante no âmbito educacional, porque ela viabiliza outra visão para ser trabalhada com o texto dramático infantil, fugindo daquela concepção de "teatrinho" tão difundido no meio escolar. Para esse fim, se faz necessário pensar estratégias de leitura que Solé (1998, p. 69):

[...] uma das características das estratégias de leitura é o fato de que não detalham nem prescrevem totalmente o curso de uma ação [...] as estratégias são suspeitas inteligentes, embora arriscadas, sobre o 
caminho mais adequado que devemos seguir. [...]. Um componente essencial das estratégias é o fato de que envolvem autodireção - a existência de um objetivo e a consciência de que este objetivo existe e autocontrole, isto é, a supervisão e a avaliação do próprio comportamento em função dos objetivos que o guiam e da possibilidade de modificá-lo em caso de necessidade.

Desse modo, estamos sugerindo uma possibilidade para se ler o texto dramático infantil fugindo da ideia de que esse texto teatral foi escrito apenas para a representação.

\section{TEATRO E LEITURA: UM PANORAMA POSSÍVEL}

A leitura, como nos afirma Jouve (2002, p. 17), "é uma atividade complexa, plural, que se desenvolve em várias direções", tornando-se fundamental na aprendizagem de qualquer pessoa, pois no ato da leitura buscamos a decodificação dos signos e o significado das palavras. Ao entrarmos em contato com o texto dramático, assim como com outros gêneros, podemos, por meio da leitura, despertar e sentir diversas emoções, viajar pelo mundo através do olhar da literatura e desenvolver uma relação entre quem lê e a obra. Conforme nos explica a pesquisadora Reis (2008), trabalhar com o texto teatral é importante porque ele pode permitir vários caminhos para chegar à interpretação, igualmente como o texto literário, em geral, principalmente pelo fato do texto dramático apresentar em sua escrita brechas que nos direcionarão a outras formas para chegarmos ao sentido do texto. Ou seja, ler por meio da leitura oralizada, em voz alta, também vai possibilitar enxergar outras percepções e descobertas. No texto dramático, o leitor precisará complementar ainda mais as lacunas deixadas no texto, principalmente quando estas estiverem nas rubricas, para poder finalmente emitir o seu posicionamento, seu tom de voz, seus gestos, exigindo um maior esforço para preencher esses vazios.

Para podermos realmente compreender a leitura de um texto de teatro, faz-se necessário prestar atenção na sua estrutura e em dois recursos primordiais de sua composição, a saber: os diálogos e as rubricas (indicações cênicas que auxiliam na interpretação e realização espacial de determinadas falas, ações e cenas textuais). Desta forma, ler um texto dramático consiste em tentar compreender o que muitas vezes o autor deixa subtendido nas rubricas ou na própria fala das personagens, exigindo, sobretudo, posturas de gestualidade e entonação. Desse modo, o ato de ter que ler performaticamente um texto dramatúrgico, seja ele infantil ou não, desvencilhandose da cena, apenas por prazer ou desfrute, proporcionará novos olhares pela e para leitura do texto literário em sala de aula ou fora dela.

Ao questionarmos os aprendizes se já realizaram a leitura de algum texto de teatro, em geral, a resposta será negativa, mas, poderemos ter como resposta que já assistiram algum espetáculo, ou apenas sabem que existe esta modalidade, mas ainda não tiveram a oportunidade de conhecerem pessoalmente. Isso acontece porque fomos acostumados a saber que o texto de teatro foi feito para ser encenado e não para ser lido em sala de aula, já que esse gênero literário, geralmente, é mais visto na representação cênica, ou seja, na ação dramática. Às vezes, e de forma rara, não pensamos em ler um texto de teatro por puro prazer, como lemos um conto ou um romance, imaginando suas cenas, refletindo sobre as ações e o enredo ou provocando a reflexão sobre a história. Nós apenas vamos ao teatro para ver a ação dos atores.

Nessa perspectiva, consideramos de suma importância trazer a leitura do texto de teatro infantil para a sala de aula, pensando na prática leitora desse gênero tão 
esquecido enquanto literatura, visto que, empiricamente, percebemos a invisibilidade do texto de teatro infantil em nossas escolas públicas ou privadas. No entanto, ele se faz presente pela ação dramática nas confraternizações e festas comemorativas, mas distante do aluno enquanto um gênero capaz de promover um maior interesse pela leitura dentro e fora do ambiente escolar. Para o pesquisador Grazioli (2007, p. 29):

A arte teatral pensada como ferramenta de crescimento pessoal desencadeia atitudes autônomas e conscientes nos jovens, levando-os a repensar e avaliar suas escolhas pessoais e culturais e, quem sabe, optar por serem consumidores ou produtores da verdadeira arte, ou seja, da arte que possibilite sua emancipação e seu crescimento.

Assim, compreendemos que o texto dramático estimula a formação do jovem, possibilitando que ele venha a redescobrir-se no cotidiano, além de alargar seu conhecimento cultural, uma vez que a reflexão pela arte e, culturalmente, as ações tomadas pelos aprendizes, os levam para um processo do exercício da cidadania, focalizando-se pelo ato de ler, e mais ainda, de ser coletivamente, pois a arte tem esse poder de junção, que leva os alunos ao processo de ensino e aprendizagem para a sua evolução enquanto leitor.

O tipo da nossa pesquisa, quanto aos objetivos, é exploratória, pois fizemos um levantamento bibliográfico para apresentar ao leitor uma proposta de leitura focalizada pelo viés do texto dramático, sendo esse na categoria infantil. Isto posto, o texto Maria Roupa de Palha (2008) da dramaturga Maria de Lourdes Nunes Ramalho (Lourdes Ramalho) servirá de base para a realização da nossa proposta metodológica voltada para a performance. É de bom alvitre saber que a definição de performance através de Zumthor (2014, p. 59), consiste em:

[...] um momento peculiar e fundamental da recepção, ela leva em conta a corporeidade do envolvido na prática discursiva, e ainda o entorno, o espaço, a situação como um todo. A performance é então um momento da recepção: momento privilegiado, em que um enunciado é realmente recebido.

Para que a leitura aconteça de forma performática, faz-se necessário não só a presença da voz ao ler o texto dramático, mas também do corpo, dos espaços encontrados dentro ou fora da sala de aula, ou seja, de tudo que esteja ao seu redor e que possa lhe dar condições para desenvolvê-la.

Desse modo, nossa pesquisa foi norteada com os postulados teóricometodológicos que nos comprovam a valorização do texto teatral infantil na escola. Para tanto, nossas considerações estão fundamentadas nas contribuições de Reverbel (1987), acerca da dramaturgia e o seu percurso histórico; Pereira (2005), que discorre sobre o teatro infantil e o olhar direcionado para a criança; Kefalás (2010), que nos auxiliará nos estudos sobre performance, dentre outros estudiosos e pesquisadores que abordam essa temática.

Nesse sentido, objetivamos com esse estudo destacar a abordagem do texto dramático na escola por meio da abordagem performática, tendo como suporte a obra supracitada, considerando uma proposta para ser desenvolvida para a sala de aula, tomando como base os estudos e propostas de Eliana Kefalás (2018). Consideramos também a especificidade do gênero trabalhado, pois o teatro pode inserir 
o aluno em atividades de grupo, ampliando a sua capacidade de se expressar em público, além de possibilitar a sua inserção na sociedade.

A nossa problemática consiste em dar visibilidade ao texto de teatro infantil, especificamente de autoria feminina brasileira, bem como em sua relevância fora da cena, haja vista que é um gênero literário praticamente esquecido enquanto texto literário, mas que é importante e relevante no nosso contexto educacional.

Metodologicamente, traçamos um percurso que comprove a relevância de se ler o texto teatral infantil no ambiente escolar, tomando como referência a abordagem de leitura performática. Desse modo, desejamos realizar uma pesquisa de natureza qualitativa, que, segundo Denzin e Lincoln (2006, p. 21): “[...] é um campo interdisciplinar, transdisciplinar [...] que atravessa as humanidades".

Sendo assim, através desse artigo, traçamos alguns caminhos que validam a pertinência da leitura por meio do texto dramatúrgico infantil. Mesmo não desenvolvendo um estudo de caso, podemos afirmar que essa abordagem pode oportunizar uma maior interação entre a turma, facilitando também o processo de inserção do aluno na sociedade, como já mencionamos acima.

\section{A FORÇA DE UMA MULHER: LOURDES RAMALHO, DO RIO GRANDE DO NORTE PARA A PARAÍBA.}

Nascida no dia 23 de agosto do ano de 1923, Maria de Lourdes Nunes Ramalho saiu do sertão de Jardim do Seridó, no Rio Grande do Norte, onde teve uma infância cercada por contadores e cantadores de histórias, pois sua família vem de uma tradição de artistas, educadores que declamavam e cantavam com suas violas, despertando assim a paixão pela cultura popular e as raízes do seu povo, para depois seguir uma jornada em Pernambuco e, posteriormente, na Paraíba, local que se consolidou como escritora e dramaturga.

Durante a adolescência, Lourdes Ramalho escreveu seu primeiro texto dramático que foi encenado na escola, espaço este que serviu durante muito tempo de palco para às suas produções. Os seus textos tinham vida curta, apenas até o dia de sua estreia, e seus temas eram direcionados para criticar, bem como denunciar a falta de qualificação dos profissionais, além das crueldades que as alunas sofriam pelas freiras do internato em que ela estudava na cidade de Pernambuco. Um desses espetáculos resultou em sua expulsão do colégio, mas serviu de impulso para que ela nunca mais desistisse de escrever.

Posteriormente, um movimento teatral surgiu no início da década de 1950, em Pernambuco, inspirado pelo Teatro de Arena, da cidade de São Paulo, tendo à frente Hermilo Borba Filho, Ariano Suassuna, dentre outros artistas que juntos criaram o Teatro Popular do Nordeste, cuja intenção consistia em expandir as manifestações teatrais, e cujos textos estavam voltados para engrandecer as características da Região Nordeste, além de reforçar as histórias que fizeram e fazem parte do imagético popular.

Assim, influenciados por esta ebulição cultural, outros grupos começaram a se formar na região. Eis que surge o Teatro do Estudante da Paraíba, que tinha por objetivo renovar a cena teatral tomando por foco os elementos da cultura popular. Em seguida, suas atividades foram encerradas, devido aos seus posicionamentos políticos durante a Ditadura Militar no Brasil. De acordo com Andrade (2011, p. 14, grifo nosso): 
$\mathrm{Na}$ década seguinte, cresce um movimento em torno do Teatro Santa Roza, em João Pessoa, e do recém-construído Teatro Municipal Severino Cabral, em Campina Grande e ainda na primeira metade dos anos de 1970, entre outros nomes da dramaturgia local, como Altimar Pimentel e Paulo Pontes, começa a ter destaque o de Lourdes Ramalho, que até então conciliava o oficio de poeta e dramaturga com o de professora.

É importante frisar que esses movimentos produziram uma verdadeira efervescência cultural. E a obra de Lourdes Ramalho, que tinha como propósito reelaborar a cena nordestina bebendo nas fontes de suas heranças culturais, passa a ter destaque em todo o cenário nacional, com relevância para os textos: Fogo-Fátuo (1974), As Velhas (1975), A Feira (1976), Eleição (1977) e Os Mal-Amados (1977).

Considerada como a dama da Dramaturgia Nordestina, Lourdes Ramalho se diferencia de outros dramaturgos, pois apresenta em seus textos aspectos peculiares de suas raízes nordestinas, além de uma linguagem bem particular. Suas obras foram fonte de pesquisadores como Diógenes Maciel e Valéria Andrade (2011), que vêm se debruçando em estudar a vida e a obra desta autora, tão importante para o cenário teatral não só nordestino, como também brasileiro, assim como empenham-se em reescrever seus textos e publicá-los para que outros estudiosos tenham acesso a essas obras.

$\mathrm{Na}$ introdução do livro Teatro [quase] completo de Lourdes Ramalho, Diógenes Maciel e Valéria Andrade (2011) dividem a obra da dramaturga em duas fases, que denominam de Primeiro e Segundo Ciclo. Segundo esses pesquisadores, os textos que correspondem ao Primeiro Ciclo da obra dramatúrgica de Lourdes Ramalho trazem temas centrados na seca, migração das famílias nordestinas, o poder político e relacionamentos inacabados, bem como às questões relacionadas ao poder feminino em nossa sociedade; todos estes marcados por denúncia e senso crítico de uma escritora que nunca teve medo de expor seus posicionamentos por meio da sua escrita.

O Segundo Ciclo, por sua vez, inicia-se a partir da década de 1990, com o texto Romance do Conquistador (1991), época em que a dramaturga prioriza a valorização das suas raízes étnicos-culturais do universo popular nordestino, especificamente às que aludem à cultura ibérica do século XVI.

No que tange aos textos publicados para o público infantil, Lourdes Ramalho apresenta "uma coletânea de 14 textos escritos em versos que abordam temas [...], desde os autos populares de natal, passando pelas histórias e artimanhas de João Grilo, até recriações de contos populares tradicionais que circulam no universo da oralidade" (LÚCIO, 2005, p. 23 - 24). A autora busca em suas produções percorrer variados caminhos da linguagem infantil, respeitando este universo e trazendo textos que resgatam as produções orais, bem como fortalecendo e enaltecendo a cultura do povo nordestino, por meio de suas criações ou adaptações dos clássicos destinados a este público.

O tópico a seguir traz um breve resumo da obra corpus desse estudo.

\section{1 Resumo da Obra}

A peça Maria Roupa de Palha (2008), escrita por Lourdes Ramalho, traz em seu enredo a história de uma menina chamada Maria, filha de um senhor de nome Amadeu, 
um viúvo que acreditava não ter mais condições de criar a menina, e por isso então decide entregá-la para morar com uma senhora identificada por "Patroa".

Após chegar na casa da senhora e ser entregue por seu pai, que logo em seguida vai embora, Maria recebe um vestido de palha que será o seu companheiro nos afazeres domésticos. Sua fiel companhia é um papagaio, que desde o início tentou alertar o pai da menina sobre o que a Patroa realmente pretendia fazer, mas foi em vão. Ele busca com afagos e cantorias diminuir a tristeza da garota, chegando até a ser ameaçado pela Patroa de ser vendido para o exterior. Os dois mantêm uma ligação tão forte que Maria Roupa de Palha, ao fazer um cafuné em sua cabeça, desfaz o feitiço da fada má, que prendia o príncipe encantado do Reino Ti-Rim-Tim-Tim no corpo do papagaio.

Maria se torna a responsável por levar até o príncipe uma caixinha com a coroa e o anel do reino. No caminho, ela percorre vários lugares em busca da resposta que lhe levará a Terra do Confim, conversando com a nuvem, estrelas, raio solar, a lua e os asteroides até chegar ao tão esperado Reino encantado. Lá, aguardando sua chegada, estava o príncipe que, como prometeu, casou-se com Maria em uma grande festa para todos os membros da cidade.

Nessa obra teatral, Lourdes Ramalho direciona o leitor a viajar pelos caminhos dos contos de fadas como Cinderela e a Gata Borralheira, cujas princesas também passam por esse processo de abandono, e principalmente por estarem a serviço dos trabalhos domésticos atribuídos por uma mulher que se apresenta como se fosse de boa índole, mas que guarda diversos sentimentos de ódio e rancor dentro de si. Assim, de acordo com Lúcio (2008, p. 40): "A imagem da mulher, dedicada aos afazeres domésticos, recompensada com o casamento, recebe outras nuances no texto de Lourdes. Do Sucesso nas viagens de Maria, depende o príncipe para se tornar rei". O presente texto é uma mistura de verso e prosa em que as personagens com características dos contos de fada jogam e se assemelham com a realidade social de muitos jovens que ao se submeter em situações semelhantes almejam uma vida mais digna.

Dessa maneira, após estas considerações da obra, propomos que o texto de Lourdes Ramalho, Maria Roupa de Palha (2008), seja mais uma possibilidade de leitura literária, para isso utilizaremos a abordagem performática proposta por Eliana Kefalás (2018), como estratégia de leitura para ser trabalhado em sala de aula.

\section{A abordagem performática focalizada na leitura do texto teatral infantil}

A abordagem da leitura performática, seja ela vocalizada ou silenciosa, pressupõe o não isolar-se com o texto, mas sim, esmiuçá-lo de forma a jogar com ele, brincar com o mesmo, descobrindo suas nuances corporais, expressivas e vocais, seja individualmente ou até mesmo em grupos. Desse modo, propomos ladear o leitor em diversos momentos sensoriais, contextualizando-o via imersão da leitura, realizada a partir do texto dramatúrgico infantil.

No momento em que realizarmos a leitura oralizada, oportunizamos aos alunos uma ligação entre o corpo e a obra, vivenciando as sensações mais diversas, oriundas dessa experiência trazida com a junção do ato de ler com expressões corporais e vocais. Quando da realização de uma leitura silenciosa, há também no corpo o despertar de sensações diferentes, por exemplo, de calafrios, medo, alegria, dentre outras (KEFALÁS, 2010), ou seja, há um frenesi emocional que pulula dos vocábulos pelo corpo. 
Neste diálogo a seguir entre o Maria e a Patroa, com a intervenção do Papagaio, é possível identificar momentos que podem despertar no leitor sensações como asco, antipatia, repulsa diante da atitude impositiva da senhora, conforme veremos abaixo:

MARIA - Minha mãe me deu lição.

PATROA - Luta de gado e roçado?

MARIA - Isso aí nunca fiz, não!

PAPAGAIO - Pronto! Armou-se a confusão!

PATROA - Pois nesta casa, menina, tudo, tudo vai fazer! Não vou criar gente fina para ter luxo, ao crescer! Como qualquer peregrina, vai aprender a viver!

PAPAGAIO - Não aguento mais! Vou me meter!

PATROA - Vai ser a minha criada, pra dessa casa cuidar, para limpar o roçado, para lavar e engomar, alimentar gado e aves! E agora - vá trabalhar! (RAMALHO, 2008, p. 74).

Diante dessa perspectiva, Kefalás (2018) vem nos dizer que a estratégia de leitura vocalizada para ser realizada em sala de aula fundamenta-se a partir de enfoques metodológicos, a saber:

Há diversas estratégias possíveis usadas na leitura em voz alta a partir do texto literário, mas seria interessante pensar a leitura vocalizada a partir de, pelo menos, dois enfoques metodológicos, distintos entre si: 1) planejando a leitura previamente à vocalização; 2) trabalhando com a improvisação, com jogos em que o imprevisível seja o elemento balizador da experiência de dar, ao texto, vozes múltiplas experimentadas em processo de criação (KEFALÁS, 2018, p. 253).

Como podemos perceber, a leitura planejada, apresentada pela professora Eliana Kefalás (2018), decorre da execução de dois enfoques metodológicos, sendo o primeiro através de um mapa sonoro, cujas modulações e intenções para a leitura já estão previamente estabelecidas, podendo ser realizado por diversas vozes, sentimentos e entonações pré-definidas em conjunto com o grupo que fará a leitura, sendo que esse agrupamento precisa estar em total harmonia, agregando uma unissonância na vocalização do texto. Já o segundo enfoque é por meio da leitura improvisada, ou seja, a partir do jogo com o texto e às diversas possibilidades que este pode nos possibilitar.

Em seguida, é possível ver um exemplo de como desenvolver o planejamento da leitura a partir do mapa sonoro, proposto pela pesquisadora Eliana Kefalás (2018). Nele, perceberemos que o comando apresentado no mapa vem dividido por meio de cores e tipos de fontes, que trazem uma informação a ser seguida, como entonação e sentimento, dentre outros aspectos, e estes deverão ser os mesmos do texto que será seguido e trabalhado em sala de aula. 


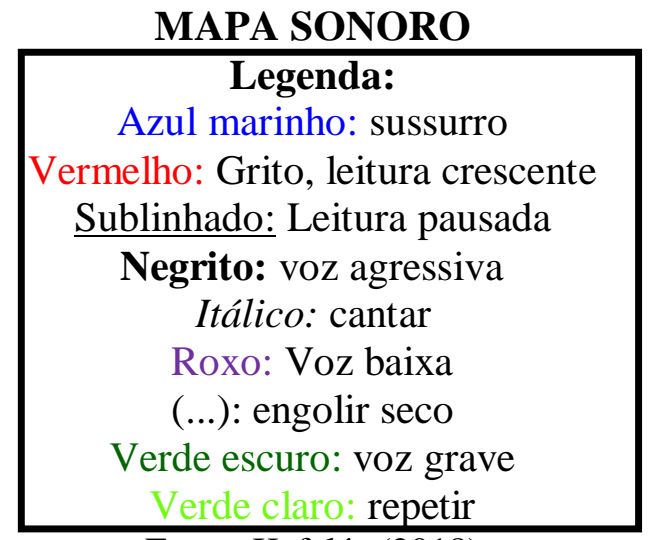

Fonte: Kefalás (2018)

Neste sentido, nossa sugestão apoia-se na realização da leitura do texto teatral infantil Maria Roupa de Palha (2008), de Lourdes Ramalho, com base no segundo enfoque metodológico apresentado por Kefalás, ou seja, a leitura improvisada, cujo direcionamento é possível mediante auxilio do professor, visto que sugerimos levar a leitura do texto dramatúrgico de forma a trabalhar alinhado com a improvisação, seguido de leitura livre, e sem definição pré-estabelecida, para entender qual a voz da personagem ou qual a entonação que se deve chegar. Nossa intenção é jogar com o texto, e buscar as possibilidades de novas enunciações, seguindo a sequência das personagens sem privilegiar protagonista e nem o vilão. Todos os alunos participam de igual por igual, contribuindo dessa forma para a construção do leitor proficiente.

\section{A abordagem metodológica performática}

Neste estudo, abordaremos a proposta de leitura performática por meio do enfoque metodológico 2 (dois) em que se utiliza-se a leitura do texto por meio de jogos improvisados, buscando evidenciar o processo criativo e das vozes múltiplas experienciadas durante o processo criativo. A seguir, segue um excerto do texto em que poderemos utilizar como exemplo para realizarmos a leitura performaticamente, estimulando os alunos a buscarem inferências e entonações seguindo o modelo de leitura compartilhada proposta por Solé (1998).

MARIA - Varre, varre, vassourinha, a chinica da galinha!

PAPAGAIO - Varre, varre, mão canhota, as pisadas da velhota!

MARIA - Varre, varre, vassourão, o pelo do rabo do cão!

PAPAGAIO - Varre sala, varre quarto, varre varanda e terreiro!

MARIA - Quem me dera que eu saísse a varrer o mundo inteiro!

PAPAGAIO - E eu para acompanhá-la fugia deste poleiro (RAMALHO, 2008, p. 75)

No trecho acima, é possível identificar a presença de palavras repetidas que, durante a leitura, podem ser estimuladas pelo mediador para seguir ritmos diferenciados, no intuito de que se diferenciem um das outras, bem como poderá ser sugerido que explorem os sons dos animais presentes nesse excerto, a fim de estimularem os discentes a jogarem com o texto por meio da leitura.

Para tanto, desenvolvemos um plano de leitura que está dividido em 6 (seis momentos) que auxiliará na execução dessa proposta a ser produzida com turmas do Ensino Fundamental II. 


\section{PLANO DE LEITURA}

OBRA: Maria Roupa de Palha

ANO: 2008

AUTORA: Lourdes Ramalho

GÊNERO: Dramaturgia para crianças.

PÚBLICO: Alunos do Ensino Fundamental II

$1^{\circ}$ Momento - Nesse primeiro momento, podemos realizar a leitura compartilhada sem buscar nenhuma intenção performática, para que os aprendizes possam conhecer o texto. Pode ser uma leitura individual ou coletiva, silenciosa ou não. Nossa sugestão é que seja coletiva, em voz alta e que o professor inicie, buscando identificar na leitura dos alunos os pontos mais performáticos. Como nesse trecho em que a Patroa manda o Papagaio ir tomar banho:

PATROA - Meu louro, coma à vontade! Seus dias estão contados! Vou vendê-lo pro estrangeiro, vou ter dinheiro guardado pra comprar sedas e rendas e sapatos delicados! E, agora, vá tomar banho, lave as penas com cuidado, logo mais se enxugue ao sol que está quente e dourado, vai viajar pro estrangeiro, onde será bem tratado! (RAMALHO, 2008, P. 77-78).

Nesta fala é perceptível que ela deve ser lida de forma dissimulada, pois mesmo sendo indicado desde o início do excerto que o Louro está com os dias contados, e a Patroa utiliza palavras que denotam atenção e carinho para com o animal, a verdade é que ela deseja poder se livrar dele. Assim, durante o processo de mediação o professor poderá sugerir outras formas de dizer as falas das personagens, podendo inverter esse jeito astucioso da senhora por tons maquiavélicos, denotando seu jeito maldoso de agir.

Também é possível que se siga a leitura completa da obra, sem precisar fazer divisão de personagens. Esse momento é importante porque revela ao professor mediador nuances do texto que sem essa leitura talvez não fosse possível, como por exemplo, passagens lúdicas ou acontecimentos temporais.

$2^{\circ}$ Momento - No segundo momento, o professor/mediador começará a buscar a performance na leitura das crianças. Nessa etapa, de forma improvisada, todos farão a leitura seguindo a sequência do texto, buscando encontrar as inflexões das falas das personagens, sem se deter ao que o autor apresenta nas rubricas. É importante deixar a criação e imaginação fluírem livremente.

Nesse trecho a seguir, um sentimento está explícito na fala de Maria: o "medo". Esse medo pode ser totalmente explorado durante a leitura ou o mediador pode permitir, (e isso seria bom que acontecesse) que os alunos percebam outras intenções da fala, como o cansaço, a fadiga, ou o desejo de se vingar do Papagaio, por perceber a exploração que a menina vem sofrendo.

MARIA - Já carreguei tanta água, já cisquei todo o pomar, já cozinhei o almoço, fiz o lanche e o jantar! E inda ter que essa roupa toda lavar e passar? Já é noite e, na fonte, tenho medo de ficar. E neste pequeno quarto como água posso arranjar para cuidar desta trouxa, enxugar, depois passar?

PAPAGAIO - Maria vá repousar que dos panos cuido eu! Deita aí bem quietinha. Coitada! Já adormeceu! Agora vou me arranjar com o poder que Deus me deu! (RAMALHO, 2008, p. 78 - 79). 
O Interessante de jogar com o texto é ter essa permissibilidade de jogar com o texto sem se preocupar com o que aparentemente é correto. Ao investir em possibilidades de intenções e interpretações, o aluno começa a descobrir novos caminhos de compreensão do texto.

$3^{\circ}$ Momento - Após realizar a leitura de forma improvisada, faz-se necessário um diálogo para que os discentes possam exercitar sua autoavaliação e a observação do outro, tentando identificar os pontos que mais chamaram a atenção no ato da leitura. Não podemos deixar de considerar que suas experiências e vivências tão importantes nesse processo de construção de sentido do texto.

$4^{\mathrm{o}}$ Momento - Depois de discutida algumas alternativas intencionais das falas, o professor pode apresentar algumas sugestões por meio de partes isoladas de uma única personagem que deverá ser lida por todos os presentes, buscando seguir a sugestão do mediador ou encontrando outro caminho. Sugerimos que essa fala de Maria seja dita com entonações rápidas, devagar, cantarolando, rindo e cansada. O importante desse momento é deixar o discente perceber que se uma mesma fala de uma personagem pode ser dita de diversas maneiras, o seu sentido não será o mesmo, ele mudará conforme a intenção ao qual estou dando.

MARIA - Com esta roupa de palha o povo vai rir de mim! Dizer: "Que menina feia - essa desse tal Confim, como o Príncipe quis noiva tão desajeitada assim?" Mas, que fazer? Já cheguei, o cofre vou entregar! Depois saio de fininho... Volto tristonha e só! Vocês concordam comigo? (RAMALHO, 2008, p. 89 - 90)

$5^{\circ}$ Momento - Seguindo o modelo de improvisação, uma sugestão é solicitar aos alunos que encontrem uma fala de algumas das personagens. Em seguida, eles realizarão a leitura de acordo com a entonação que considerarem melhor. Posteriormente, essa etapa será finalizada com a leitura do texto na íntegra, respeitando tudo o que fora descoberto.

$6^{\circ}$ Momento - A última etapa desse processo é feita com a leitura na íntegra do texto, que poderá ser realizada no pátio ou auditório da escola para toda a comunidade escolar. É importante considerar em todo esse processo que não existe leitura melhor ou pior, assim como personagem principal ou secundário. Todos terão a mesma oportunidade de passar por todas as personagens do texto, descobrindo assim uma nova possibilidade de estar presente e se fazer presente em uma atividade em sala de aula e de poder interagir recriando.

\section{Considerações finais}

O presente artigo buscou, através das discussões acerca da literatura dramática infantil, proporcionar a sua inserção no âmbito educacional, trazendo uma sugestão de leitura partindo da abordagem do método performático. Para tanto, levamos em consideração que o texto teatral infantil é um gênero que já faz parte do nosso cotidiano desde a antiguidade, nas festividades escolares e datas comemorativas, cuja encenação é marcada por espetáculos de cunhos pedagógicos e moralizantes.

Nesse contexto educacional, sugerimos abordar o texto por outro viés, buscando a leitura do mesmo de forma performática, a fim de oportunizar aos discentes um maior contato com a obra na íntegra, ampliando o conhecimento reflexivo e crítico 
do aluno. Assim, ler literatura em sala de aula é um recurso que possibilita a formação do leitor, proporcionando que ele jogue o jogo do texto de forma improvisada e desprovida de intenções pedagogizantes, pois aumenta ainda mais a compreensão para o texto literário.

Portanto, acreditamos que com esse trabalho possamos incentivar e mostrar a relevância do texto dramatúrgico infantil, para que o discente possa ter não somente mais um gênero para se trabalhar em sala de aula, mas uma nova oportunidade de conhecer um gênero de leitura dinâmica, sem ter que priorizar leitores mais proficientes ou menos tímidos, visto que o propósito maior da leitura vocalizada consiste em dar voz a todos os aprendizes, ficando a personagem protagonista "na mão" de todos os alunos, pois com a performance realizada, todos têm a chance de ler de forma igual, sem separação de personagem principal ou secundário todas as personagens do texto.

\section{REFERÊNCIAS}

CAMAROTTI, M. A linguagem do teatro infantil. 3ed. Recife: Ed. Universitária da UFPE, 2005.

DENZIN, N. K.; LINCOLN, Y. S. Planejamento da pesquisa qualitativa: teorias e abordagens. Porto Alegre: Artmed, 2006.

FERREIRA, T; FALKEMBACH, M. F. Teatro e Dança nos anos iniciais. Porto Alegre: Mediação, 2012.

FONSECA, J. J. S. Metodologia da pesquisa científica. Fortaleza: UEC, 2002.

GIL, A. Como elaborar projetos de pesquisa. 4ed. São Paulo: Atlas, 2007.

GRAZIOLI, F. T. Teatro de se ler: o texto teatral e a formação do leitor. Passo Fundo: Ed. Universidade de Passo Fundo, 2007.

JOUVE, V. A leitura. Tradução de Brigitte Hervot. São Paulo: Editora UNESP, 2002.

KEFALÁS, E. Corpo a corpo com o texto na formação do leitor literário. Campinas : Autores Associados, 2010. (Coleção formação de professores).

KEFALÁS, E. O jogo do texto no ensino da literatura: por uma metodologia performática. In : Literatura e Outras Artes : Interfaces, reflexões e dialógos com o ensino. CARVALHO, A. S. (org.). João Pessoa: Editora da UFCG, 2018.

LÚCIO, A. C. M. Teatro infantil e Cultura popular. Campina Grande: Bagagem, 2005.

MANGUEL, A. Uma história da leitura. Trad. Pedro Maia Soares. - São Paulo: Companhia das Letras, 1997.

PEREIRA, S. M. C. Teatro Infantil: Um olhar para o desenvolvimento da criança. Caderno de Filosofia e Psicologia da Educação. Ano III, n.4, Vitória da Conquista: Edições Uesb, p. 67 - 88, 2005. 
RAMALHO, M. de L. N. Maria Roupa de palha. In: Maria Roupa de palha e outros textos para crianças. Maria de Lourdes Nunes Ramalho. Organização e Introdução: Valéria Andrade e Ana Cristina Marinho Lúcio. Campina Grande: Editora Bagagem, 2008.

REIS, M. da G. M. do. O texto teatral e o jogo dramático no ensino de Francês Língua Estrangeira. Tese Apresentada ao Programa de Pós-Graduação em Língua e Literatura Francesa de Departamento de Letras Modernas da Faculdade de Filosofia, Letras e Ciências Humanas da Universidade de São Paulo, para a obtenção de Título de Doutor. São Paulo, 2008

Disponível em: http://www.teses.usp.br/teses/disponiveis/8/8146/tde-02122008171004/pt-br.php Acesso em: 10 de outubro de 2015.

REVERBEL, O. Teatro: Uma síntese em atos e cenas. Porto Alegre: L\&PM, 1987.

SILVA. I. M. M. Literatura em sala de aula: da teoria literária à prática escolar. 2003. Disponível em: http://www.pgletras.com.br/Anais-30Anos/Docs/Artigos/5.\%20Melhores\%20teses\%20e\%20disserta\%C3\%A7\%C3\%B5es/5. 2_Ivanda.pdf Acesso em: 10 de outubro de 2015.

SOLÉ, M. Estratégias de leitura. Trad. Cláudia Schilling. - 6 ed. - Porto Alegre: Artmed, 1998.

ZUMTHOR, P. Performance, recepção, leitura. ed. 2. Trad. Jerusa Pires Ferreira, Suely Fenerichc. São Paulo: COSAC NAIFY, 2014.

Recebido em 20 de junho de 2019

Aceito em 23 de agosto de 2019 